\title{
Seasonal variations of cloud and precipitation at Syowa station, Antarctica
}

\author{
Hiroyuki Konishi, ${ }^{1}$ Makoto Wada, ${ }^{2}$ Tatsuo Endoh ${ }^{3}$ \\ ${ }^{1}$ Osaka-Kyoiku University, 4-698-1, Asahigaoka, Kashiwara, Osaka 582, Japan \\ ${ }^{2}$ National Institute of Polar Research, Kaga 1-9-10, Itabashi-ku, Tokyo 173, Japan \\ ${ }^{3}$ Institute of Low Temperature Science, Hokkaido University, Sapporo 060, Japan
}

\begin{abstract}
Long-term observations of precipitating clouds were carried out by a vertical pointing radar and plan-position indicator (PPI) radar at Syowa station $\left(69.0^{\circ} \mathrm{S}, 40.5^{\circ} \mathrm{E}\right)$, Antarctica, in 1989 . The observations revealed that there were three abundant snowfall seasons at Syowa station and the amount of snowfall was uniform in all seasons except summer. The amounts of precipitation in autumn, winter and spring were 74,74 and $53 \mathrm{~mm}$ (liquid water equivalent), respectively. The amounts of precipitation in autumn and winter were large at Syowa station in 1989. However, the amount of precipitation on the inland ice is expected to be small in winter, indicated by the distributions of precipitation measured by the PPI radar.

The occurrence frequencies of cloud vortices which brought snowfall to Syowa station increased in the autumn and spring seasons, corresponding to the activity of the circumpolar trough. However, the activities of cloud systems that bring precipitation weaken in spring when the sea-ice area expands to low latitudes, because of a lower supply of heat and vapor. Thus the activities of cloud vortices are also weakened above the sea ice.
\end{abstract}

\section{INTRODUCTION}

Measurement of precipitation using a snow gauge presents severe problems, since it is almost impossible to distinguish between precipitation and drifting snow in the strong winds that often accompany precipitation. In the present study, a method of estimating the amount of snowfall by using continuous meteorological radar data is described. This method can provide the amount of snowfall in each series of snowfall events because the radar reflectivity converted to snowfall intensity is measured at short time intervals automatically, irrespective of wind speed. The analysis also provides useful information on the mesoscale structure of clouds causing precipitation. Previous studies estimating the amount of snowfall in Antarctica (e.g. Budd, 1966; Bromwich, 1990) seldom refer to the structure of precipitation clouds, as they emphasize the results rather than the causes of precipitation.

The present study also deals with seasonal variations of

Table 1. Specifications of vertical-pointing and PPI radar

\begin{tabular}{lll}
\hline & Vertical pointing & PPI \\
\hline Carrier frequency & $9410 \mathrm{MHz}$ & $9740 \mathrm{MHz}$ \\
Peak power & $40 \mathrm{~kW}$ & $40 \mathrm{~kW}$ \\
Pulse width & $0.5 \mu \mathrm{s}$ & $0.5 \mu \mathrm{s}$ \\
Repetition frequency & $750 \mathrm{pulse} \mathrm{s}^{-1}$ & $750 \mathrm{pulse} \mathrm{s}^{-1}$ \\
Receiver sensitivity & $-103 \mathrm{dBm}$ & $-105 \mathrm{dBm}$ \\
Antenna diameter & $2.4 \mathrm{~m}$ & $1.2 \mathrm{~m}$ \\
Revolution & - & $2 \mathrm{rpm}$ \\
Data resolution & $50 \mathrm{~m}$ & $500 \mathrm{~m}$ \\
Data range & $6.4 \mathrm{~km}$ & $64 \mathrm{~km}$ \\
Data interval & $10 \mathrm{~s}$ & $18 \mathrm{~min}$ \\
\hline
\end{tabular}

precipitation phenomena. Since the sea-ice edge varies seasonally from 200 to $1500 \mathrm{~km}$ off Syowa station and the surface temperature varies from $0^{\circ}$ to $-40^{\circ} \mathrm{C}$, precipitation phenomena affected by these factors vary with the season. The seasonal changes of atmospheric circulation in the Southern Hemisphere are related to semi-annual oscillations of the circumpolar trough (Van Loon, 1984). The symmetric circumpolar zone of low pressure at high latitudes retreats toward the coast of Antarctica in March and October (Streten, 1980). The clouds and precipitation around Syowa station are examined as possible indicators for impacts of the seasonal oscillation.

\section{METHODS OF OBSERVATION}

Long-term observations of precipitating clouds were carried out by a vertically pointing radar and plan-position indicator (PPI) radar at Syowa station $\left(69.0^{\circ} \mathrm{S}, 40.5^{\circ} \mathrm{E}\right.$ ), Antarctica, in 1989. Syowa station is situated on the north side of the Ongul Islands near the east coast of LutzowHolm Bay. The specifications of the vertical radar and the PPI radar are summarized in Table 1. Their detailed characteristics are specified by Wada (1990) and Konishi (1992).

A highly sensitive snow gauge (Konishi and others, 1988) was used to measure snowfall rate. The weight of snow falling in a bucket on a balance was measured automatically at $1 \mathrm{~min}$ intervals and the data were computer-monitored. The minimum detectable snowfall rate for this gauge is $0.062 \mathrm{~mm} \mathrm{~h}^{-1}$ (liquid water equivalent). The electric balance was shielded by wooden walls to protect it from strong winds. However, we used the weight data only when the wind speed was $<5 \mathrm{~ms}^{-1}$, because the balance measured 

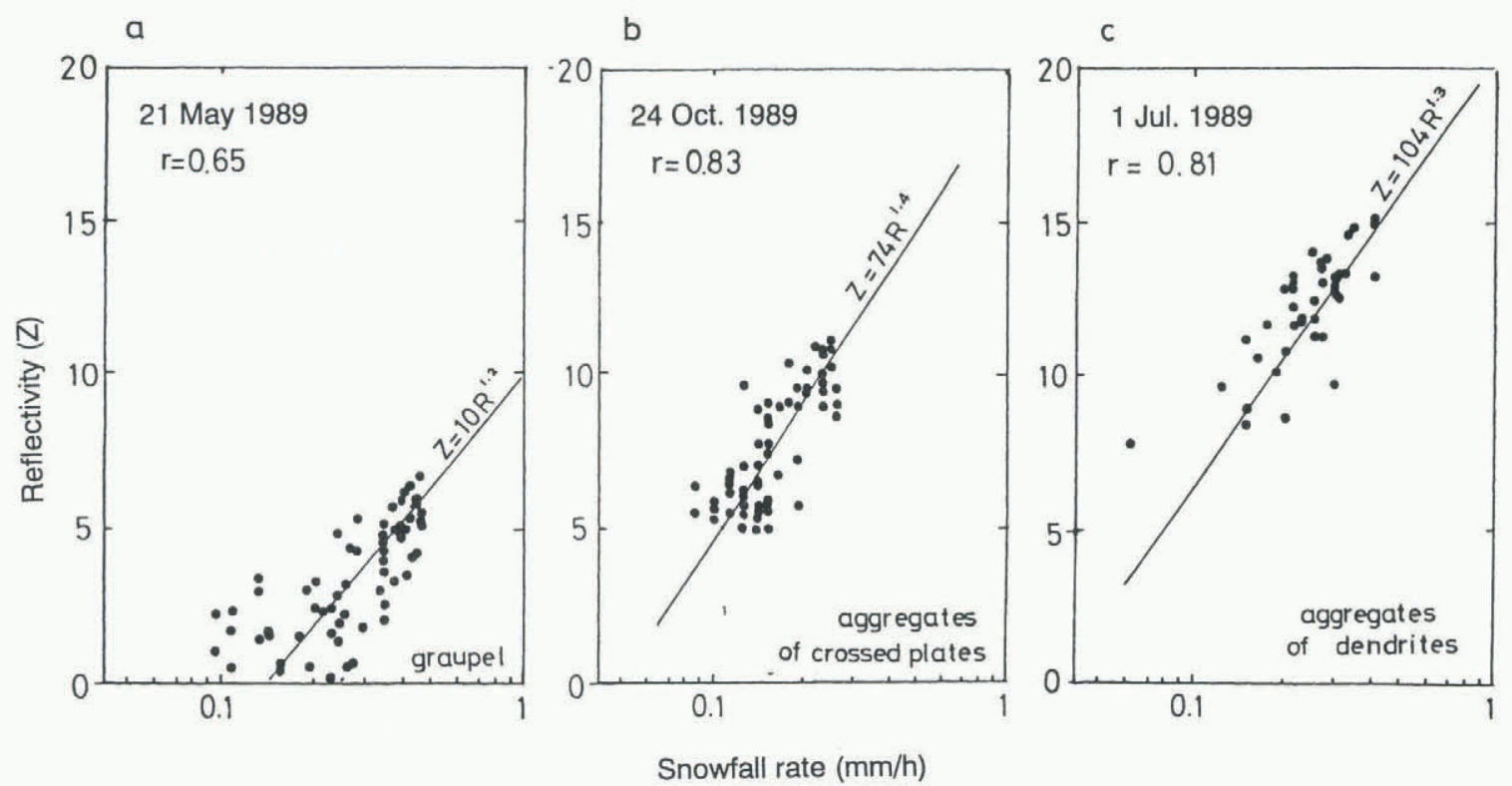

Fig. 1. Relationship between radar reflectivity factor, $Z$, and snowfall rate, $R$, observed in a series of snowfalls at Syowa station. The types of crystals were mainly graupel $(a)$, aggregates of crossed plates (b) and aggregates of dendrites $(c)$.

the weight not only of precipitation particles but also of blowing snow particles.

Surface synoptic data such as temperature, humidity, pressure and wind velocity and direction were measured every hour, and upper-air sounding data were obtained twice a day at 00Z (03LT) and 12Z (15LT) at Syowa station.

Sea-ice extent was derived from weekly reports of satellite data obtained by the U.S. Navy-National Oceanic and Atmospheric Administration Joint Ice Center. Synoptic charts were also used to trace the trajectories of low-pressure centers in twice daily European Centre for Medium-range Weather Forecasts analysis grid data for $1000 \mathrm{hPa}$, at a resolution of $2.5^{\circ}$.

\section{ESTIMATION OF PREGIPITATION AMOUNT}

The relationship between the radar reflectivity factor $Z$ $\left(\mathrm{mm}^{6} \mathrm{~m}^{-3}\right)$ and the snowfall rate $R\left(\mathrm{~mm} \mathrm{~h}^{-1}\right)$ is usually expressed as $Z=B R^{\beta}$ where $B$ and $\beta$ are empirically determined constants. Three examples of the $Z-R$ relationship are shown in Figure 1, representing different types of snow

Table 2. Values of $B$ and $\beta$ in the $Z-R$ relation derived from 14 snowfall events observed at Syow a station in 1989

Date $\quad B \quad \beta \quad$ Temperature Type of crystals

${ }^{\circ} \mathrm{C}$

\begin{tabular}{lrrrl}
\hline 28 Feb. & 61.6 & 1.21 & -1.4 & Aggregates of dendrites \\
02 Mar. & 62.3 & 1.32 & -3.8 & Aggregates of dendrites \\
13 Mar. & 17.1 & 1.26 & -7.2 & Graupel \\
07 May & 26.3 & 1.27 & -18.0 & Column \\
21 May & 11.0 & 1.28 & -16.9 & Graupel \\
19 Jun. & 17.0 & 1.15 & -21.6 & Column, thick plate \\
21 Jun. & 7.6 & 1.31 & -14.6 & Combination of bullets \\
01 Jul. & 45.7 & 1.02 & -10.5 & Aggregates of dendrites \\
24 Jul. & 16.4 & 1.29 & -22.9 & Combination of bullets \\
02 Oct. & 16.5 & 1.30 & -12.6 & Graupel-like \\
03 Oct. & 22.0 & 1.29 & -16.0 & Graupel-like \\
24 Oct. & 63.0 & 1.52 & -2.5 & Aggregates of crossed plates \\
25 Oct. & 46.7 & 1.40 & -5.3 & Aggregates of dendrites \\
31 Oct. & 40.4 & 1.21 & -10.0 & Aggregates of dendrites
\end{tabular}

particles. These data are from single snowfall events on 21 May, 24 October and 1 July 1989. The figure compares the average reflectivity, $Z$, calculated from 30 pulses of the vertical pointing radar, with the corresponding snowfall rate, $R$, measured by the gauge over $5 \mathrm{~min}$ intervals. Because the radar reflectivity below the $400 \mathrm{~m}$ level was influenced by ground clutter, only data above $400 \mathrm{~m}$ are used in the plot. The values of $B$ and $\beta$ for each snowfall are determined from linear fits to the $\log -\log$ data of Figure 1.

Values of $B$ and $\beta$ obtained in 1989 are shown in Table 2, together with the type of snow crystals and the daily mean temperature. These values of $B$ and $\beta$ are mean values over several series of observations in the day. Since snowfall is usually accompanied by strong wind, a total of only 14 days occurred which were suitable for these observations to be made. $B$ ranged from 7.6 to 63.0 , and $\beta$ from 1.02 to 1.52 . $\beta$ is adequately represented by an average value of 1.3 (mean $=1.27$; std dev. $=0.11$ ). These values are almost the same as those summarized for various types of solid precipitation by Sato and others (1981).

Comparing the cases of graupel on 21 May and aggregates of dendrites on 1 July, the radar reflectivity factors of the former were about 7 times greater than those of the latter at the same snowfall rate. If we use the same values of $B$ and $\beta$ for all precipitation, the estimated snowfall rates may contain large errors. We must use the best $Z-R$ relation for each type of snow particle to estimate the snowfall rates accurately by using radar data. However, it is impossible to detect the types of snow particles continuously in the strong wind conditions that often prevail in Antarctica. Because the types of snow particles are approximately defined by the surface air temperature, the values of $B$ can be parameterized by air temperature. A large value for $B$ is induced at higher temperatures, when the snow particles are typically aggregates of dendrites, while a small value for $B$ is induced at lower temperature when the snow particles are typically columns or bullets. The dependence of $B$ on temperature in Table 2 is illustrated in Figure 2. It can be seen that the relation between $B$ and daily mean surface temperature, $T$ $\left({ }^{\circ} \mathrm{C}\right)$, is approximated by the regression curve $B=\exp (4.11$ $\left.-7.18 \times 10^{-2} \times T\right)$. Figure $3 \mathrm{~b}$ shows the amount of daily snow- 
fall calculated using the $Z-R$ relation, with $B$ selected according to this temperature dependence and $\beta$ set to 1.3.

Precipitation was detected by the radar on more than 130 days in 1989. Almost all the daily amounts of snowfall were less than $5 \mathrm{~mm}$. The total amount of snowfall was deduced to be $204 \mathrm{~mm}$ in 1989. Since the correlation coefficient of the regression in Figure 2 is 0.73 , the error in this estimate of the amount of snowfall is about $36 \%$.

Figure 3 a represents variations in mean sea-level pressure shown as deviations from 30 day mean values. The figure indicates that the snowfall usually occurred when the deviation of pressure was negative. This suggests that the snowfalls were associated with low-pressure systems. Carleton (1992) also noted that synoptic-scale cyclones are important in the supply of moisture in the form of clouds and precipitation in Antarctica. However, snowfalls did not always occur whenever the deviation of pressure was negative. Some lows did not bring snowfall to Syowa station.

\section{SEASONAL VARIATIONS OF PRECIPITATION AMOUNT, 1989}

Changes of the surface air temperature and sea-ice extent were investigated to determine whether they affect precipitation at Syowa station. Seasonal variations of surface air temperature at Syowa station, shown in Figure 4a, are represented by averaged values at intervals of 10 days. Assuming that the winter season is defined by the persistence of low temperatures, it lasted from May to September in 1989. The autumn and spring seasons are similarly defined by the persistence of a tendency for temperature to decrease and increase, respectively. In 1989, these seasons lasted from February to April and from October to November, respectively.

The sea-ice extent along longitude $40^{\circ} \mathrm{E}$ is shown in Figure $4 \mathrm{~b}$. The autumn season defined by the air temperature corresponds with the season of minimum sea ice. The winter season corresponds with the season of expansion of the sea ice, and the spring and summer season corresponds with the season of rapid reduction of the sea ice.

Figure 3b indicates that in 1989 there were three seasons with relatively abundant snowfall at Syowa station. The

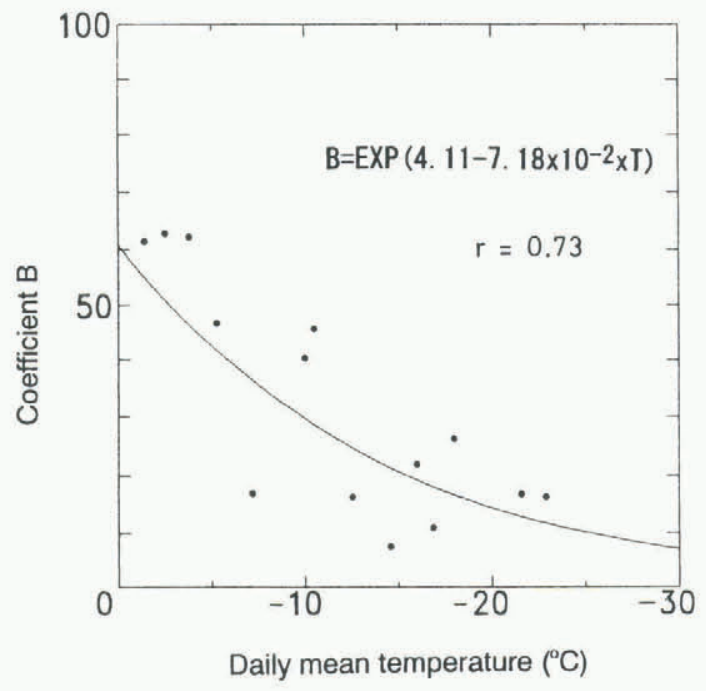

Fig. 2. Dependence of $B$ on daily mean surface air temperature based on the values summarized in Table 2.

longest snowy season was in autumn. The total amount of snowfall in this season was about $74 \mathrm{~mm}$. The total amount of snowfall in winter was also $74 \mathrm{~mm}$. The other snowy season was spring; the total amount of snowfall in this season was $53 \mathrm{~mm}$. The peak value of daily snowfall in this season was $11.0 \mathrm{~mm} \mathrm{~d}^{-1}$, larger than those in other seasons. This indicates that the amount of snowfall tended to be larger for each individual snowfall event in this season than for those in other seasons.

The precipitation amounts shown in Figure $3 \mathrm{~b}$ were derived from vertical radar data, which were obtained at only one observation point, Syowa station. Thus these values are less representative of the area around Syowa station than are those measured by PPI radar within an area extending $64 \mathrm{~km}$ around Syowa station. The monthly accumulated snowfall rate is shown in Figure 5, where the values have been estimated from the PPI radar data at $2.0^{\circ}$ elevation angle, using the $Z-R$ relation $Z=53 R^{0.78}$. This $Z-R$ relation has been deduced from a comparison between the snowfall rate at Syowa station and the radar reflectivity
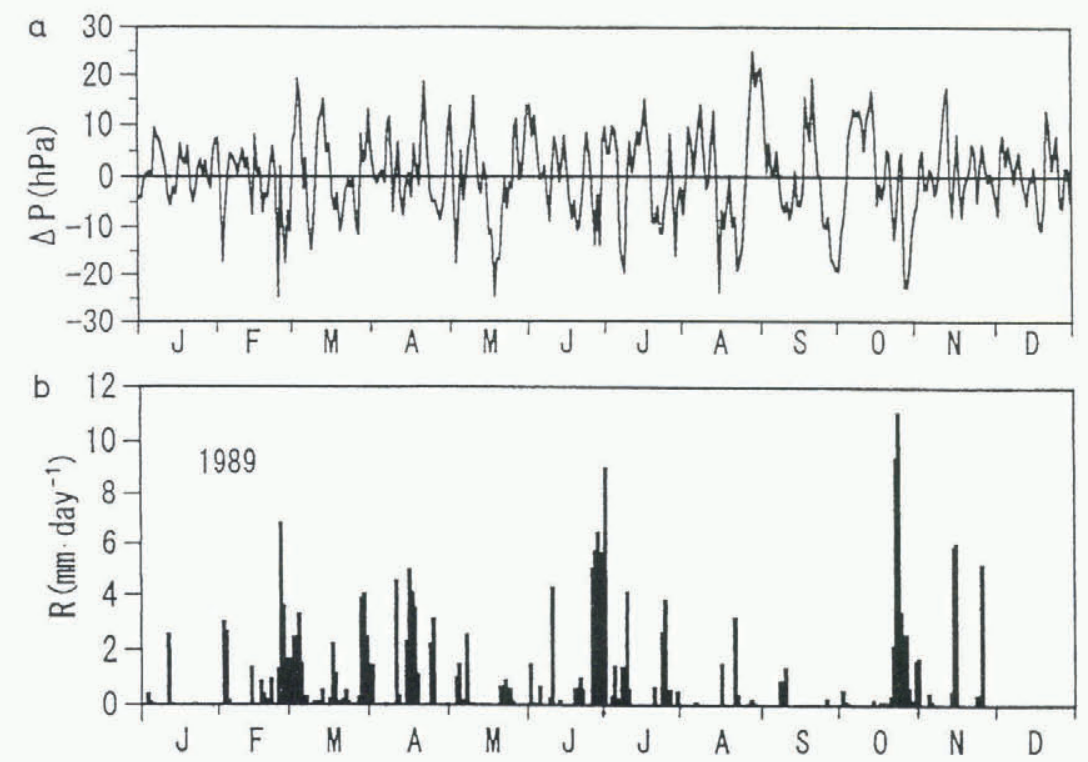

Fig. 3. (a) Deviation of surface pressure from 30 day mean values. (b) Daily snowfall rate calculated from vertical pointing radar data. 
factor $10 \mathrm{~km}$ north of Syowa station, while sweeping at $6.0^{\circ}$ elevation angle. The site of the PPI radar data (to be compared to the snowfall rate) was decided by consideration of the drifting distance due to the horizontal wind. Since the height attained at a distance of $10 \mathrm{~km}$ at $6.0^{\circ}$ elevation angle is $1000 \mathrm{~m}, 1000$ seconds are needed for snow particles to reach the ground, assuming a falling speed of $1 \mathrm{~m} \mathrm{~s}^{-1}$, which corresponds to a distance of $10 \mathrm{~km}$ drift in a horizontal wind of $10 \mathrm{~m} \mathrm{~s}^{-1}$. Almost all precipitation at Syowa station occurred in northerly wind.

The small amount of snowfall near the periphery of the observation circle shown in Figure 5 is due to the radar beam reaching the upper parts of precipitating clouds or passing above the cloud tops. Since the radar-echo height was $2.2 \mathrm{~km}$ at a distance of $64 \mathrm{~km}$ at $2.0^{\circ}$ elevation angle, and the heights of echo tops are mostly lower than $4 \mathrm{~km}$ at Syowa station (Konishi and others, 1991), the radar beam reached the upper part of clouds or passed above the cloud top near the periphery of the circle. Thus the radar-echo intensity was often small near the periphery.

The snowfall distribution shows that the maximum falls every month were localized near the coast near Syowa station. This local increase of snowfall was caused by orographic effects along the slope near the coast. However, careful investigation reveals some differences in the distribution of snowfall in autumn, spring and winter. In the autumn and spring, the snowfall maxima extend $10-20 \mathrm{~km}$ into the continent, whereas, in winter the peak snowfall occurs on the coast or on the sea, and the snowfall is less enhanced. The differences in distribution suggest that the amount of snowfall is larger in autumn and spring than in winter.

\section{SEASONAL TENDENGY OF LOW-PRESSURE CENTER TRAJECTORIES}

Figure 6 shows trajectories of low-pressure centers progressing south of $60^{\circ} \mathrm{S}$ in the area $0-45^{\circ} \mathrm{E}$ in 1989 . The trajectories indicate that the low-pressure centers mainly move eastward, although sometimes they remain stationary or move westward at a high latitude near the continent. The well-developed lows often dissipate near the coast after attaining a high latitude. The lows are classified by trajectory into two groups: one dissipating near the coast, the other moving to the east along the coast. The moving lows often appear in winter and spring, especially in May. In late winter and spring (August-November) some lows pass to the east and retreat Equatorward.

Seasonal variations in the trajectories of low-pressure centers are summarized in Table 3. In total, 64 lows dissipated in the area and 27 lows moved to the east. The ratio between the numbers of dissipating lows and moving lows changed with the season, the percentage of dissipating lows being $81 \%$, $72 \%$ and $58 \%$ in autumn, winter and spring, respectively.

The numbers in parentheses in the table show the frequency of precipitation lasting more than 10 hours for each type of low-pressure system. Almost all of the longest precipitation events at Syowa station are associated with dissipating lows. These low-pressure centers usually approach the continent and stay several tens of hours. Therefore the dissipating lows in the area contribute more water supply near Syowa station than do the passing lows.
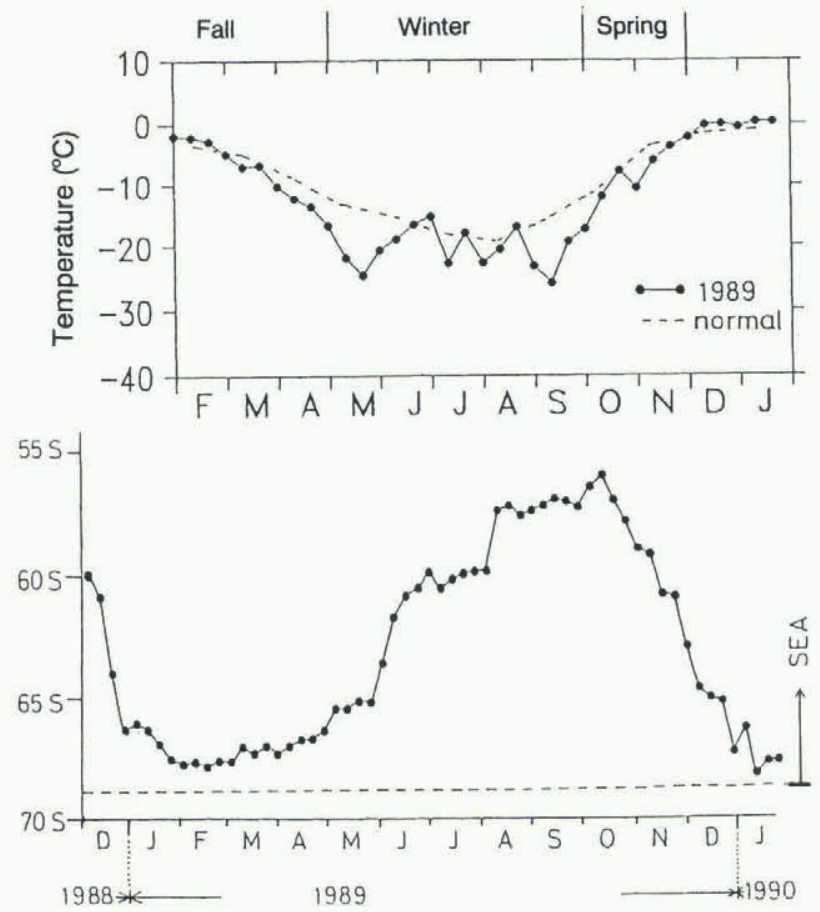

Fig. 4. (a) 10 day averages of temperature observed at Syowa station. Solid line and dashed line show values in 1989 and in a normal year, respectively. (b) Sea-ice edge along longitude $40^{\circ} \mathrm{E}$ defined as the boundary of ice concentration larger than $80 \%$.

\section{DISGUSSION AND CONGLUSIONS}

Precipitation phenomena at Syowa station, Antarctica, were observed continuously using two kinds of radars in 1989. The results reveal that the total amount of snowfall was deduced to be $204 \mathrm{~mm}$ in 1989. This is lower than the values in earlier works (Kikuchi and others, 1981) near Syowa station; however, the comparison with other results is meaningless since the methods of measurement are very different. It is thought that our results are more reliable, because the measurements were carried out at short time intervals continuously through the year.

The results also reveal that there were three seasons of abundant snowfall at Syowa station, and the amount of snowfall was uniform in all seasons except summer. The amounts of precipitation (liquid water equivalent) for each season were 74,74 and $53 \mathrm{~mm}$ for autumn, winter and spring, respectively. However, the amount of snow inland from Syowa station is expected to be small in winter, indicated by the distributions of precipitation measured by the PPI radar. Thus the main seasons contributing to the snow accumulation are autumn and spring, when the circumpolar trough develops and moves poleward to high latitudes. However, there are some differences in characteristics of precipitation between these two seasons.

The amount of precipitation in spring associated with a few snowfall events was as large as the amount of precipitation in autumn associated with frequent snowfall events. However, the activities of cloud systems that bring precipitation are weakened in spring because of a reduced supply of water vapor as the sea ice expands Equatorward. The liquid water content data described by Konishi and others (1994) suggest that cloud systems are more influenced by the seaice area in spring than in autumn. And the seasonal variation of the frequency of solid-phase clouds corresponds to the seasonal variation of the sea-ice edge. Thus the 


\section{Monthly snowfall rates}
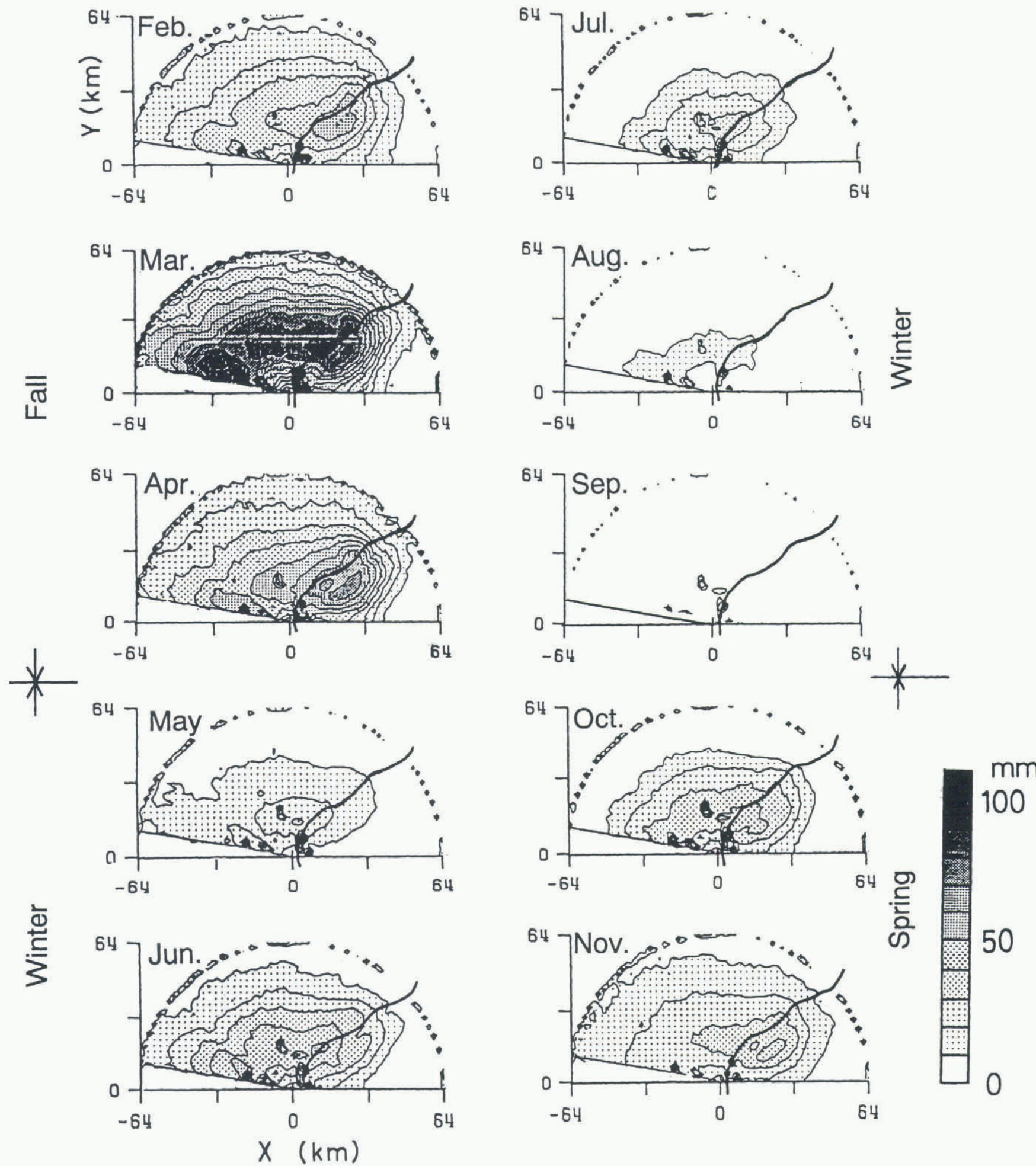

Fig. 5. Monthly accumulated snowfall rate obtained by PPI radar. The amount of snowfall is contoured every $10 \mathrm{~mm} \mathrm{month}^{-1}$. The thick solid line showes the coast of Antarctica.

frequency of occurrence of low-level clouds was small in spring, as described in Konishi and others (1991).

Therefore, if the number of snowfall events changes from year to year due to some cause such as changing trajectories or the frequency of lows, it is expected that the interannual variation of the amount of precipitation will be less in autumn but greater in spring. The amount of precipitation summed for several snowfall events does not greatly affect the total amount of precipitation in autumn, because precipitation in autumn occurs in many snowfall events. In con- trast, in spring, precipitation occurs in only a few snowfall events. Furthermore, since the sea-ice extent in late spring decreases rapidly, it is expected that the location of the seaice edge will also vary from year to year, producing variations in the amount of precipitation from year to year. It is thus expected that the amount of precipitation around Syowa station consists mainly of a relatively constant component in autumn and a yearly fluctuating component in spring.

Since this study is based on only one year's data at one 

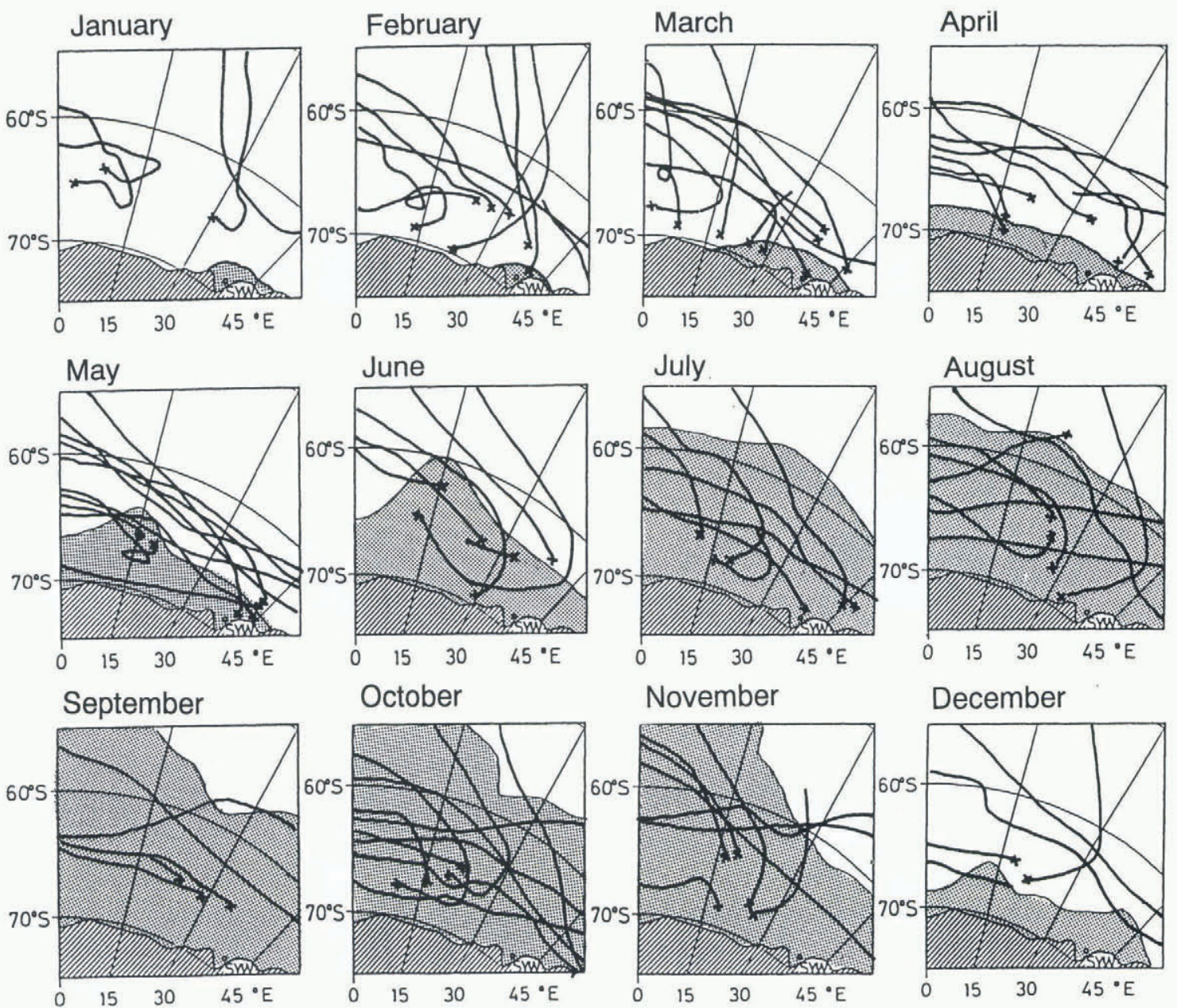

\section{October}

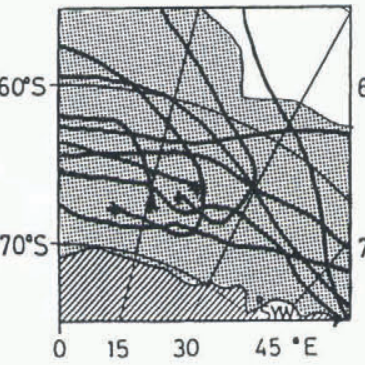

November

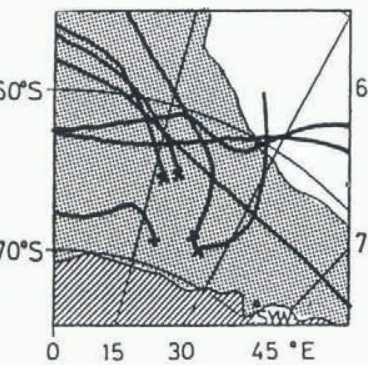

\section{December}

Fig. 6. Trajectories of low-pressure centers south of latitude $60^{\circ} \mathrm{S}$. Crosses show where low-pressure centers dissipated. The hatched region shows the continent, and the shaded area shows the sea-ice extent at the beginning of each month.

observation point, further work is needed to compare these results with data at other points and from other years.

\section{ACKNOWLEDGEMENTS}

This study was carried out as a link in the chain of the project of Antarctic Climate Research (ACR). The authors wish to thank all the wintering members of the 30th Japanese Antarctic Research Expedition for their support in setting up and maintaining the observation instruments. They especially wish to thank the wintering members of the Japanese Meteorological Agency for their generous offering of useful data.

Table 3. Numbers of types of low-pressure systems in 1989 $\left(0-45^{\circ} \mathrm{E}, 60-70^{\circ} \mathrm{S}\right)$

\begin{tabular}{lccc}
\hline Season & Dissipating & Passing & Total \\
\hline Autumn (Feb.-Apr.) & $22(18)$ & $5(1)$ & $27(19)$ \\
Winter (May-Sept.) & $26(9)$ & $10(0)$ & $36(9)$ \\
Spring (Oct.-Nov.) & $11(9)$ & $8(3)$ & $19(12)$ \\
Summer (Dec.-Jan.) & $5(3)$ & 4 & $9(3)$ \\
Total & $64(39)$ & $27(4)$ & $91(43)$ \\
& & & \\
\hline
\end{tabular}

Note: Numbers in parentheses indicate the frequency of precipitation associated with low-pressure systems of long duration ( $>10$ hours) at Syowa station.

\section{REFERENCES}

Bromwich, D. H. 1990. Estimates of Antarctic precipitation. Nature, $343(6259), 627-629$.

Budd, W. F. 1966. Glaciological studies in the region of Wilkes, eastern Antarctica, 1961. ANARE Sci. Rep., Ser. A (IV). Glaciol. 88.

Carleton, A. M. 1992. Synoptic interactions between Antarctica and lower latitudes. Aust. Meteorol. Mag., 40, 129-147.

Kikuchi, K., N. Sato and G. Kondo. 1981. On the precipitation intensity at Syowa Station, Antarctica. Natl. Inst. Polar Res. Mem., Special Issue 19, 167-177.

Konishi, H. 1992. Antarctic climate research data. Part 5. PPI radar data at Syowa Station, Antarctica from February to December 1989. JARE Data Rep. 173. (Meteorology 28.)

Konishi, H., T. Endoh and G. Wakahama. 1988. [A new snow gauge using an electric balance.] Seppyo, 7. Jpn. Soc. Snow Ice, 50(1), 3-7. [In Japanese with English summary.]

Konishi, H., S. Murayama, H. Kakegawa, M. Wada and S. Kawaguchi. 1991. Annual variation of snowfall and radar echo structure of snow clouds at Syowa Station, Antarctica. Proc. NIPR Symp. Polar Meteorol. Glaciol. 5, 90-96.

Konishi, H., M. Wada and T. Endoh. 1994. Seasonal variation of precipitating clouds near Syowa Station, Antarctica derived from liquid water content data. F. Meteorol. Soc. Jpn, 72, 709-717.

Sato, N., K. Kikuchi, S. C. Barnard and A. W. Hogan. 1981. Some characteristic properties of ice crystal precipitation in the summer season at South Pole Station, Antarctica. 7. Meteorol. Soc. Jpn, 59, 772-780.

Streten, N. A. 1980. Some synoptic indices of the Southern Hemisphere mean sea level circulation 1972-1977. Mon. Weather Rev., 108, 18-36.

Van Loon, H. 1984. Interannual variations in the half-yearly cycle of pressure gradients and zonal wind at sea level on the Southern Hemisphere. Tellus, 36A, 76-86.

Wada, M. 1990. Antarctic climate research data. Part 2. Radar and microwave radiometer data at Syowa Station, Antarctica from March to December 1988. JARE Data Rep. 153. (Meteorology 24.) 